Neurosurg Focus 27 (3):E10, 2009

\title{
History of cervical disc arthroplasty
}

\author{
Ali A. BaAJ, M.D., ${ }^{1,2}$ Juan S. Uribe, M.D., ${ }^{1}$ Fernando L. Vale, M.D., ${ }^{1}$ \\ Mark C. Preul, M.D., ${ }^{2}$ and Neil R. Crawford, Ph.D. ${ }^{2}$ \\ ${ }^{1}$ Department of Neurosurgery, University of South Florida, Tampa, Florida; and ${ }^{2}$ Division of Neurosurgery, \\ Barrow Neurological Institute, Phoenix, Arizona
}

\begin{abstract}
Enthusiasm for cervical disc arthroplasty is based on the premise that motion-preserving devices attenuate the progression of adjacent-segment disease (ASD) in the cervical spine. Arthrodesis, on the other hand, results in abnormal load transfer on adjacent segments, leading to the acceleration of ASD. It has taken several decades of pioneering work to produce clinically relevant devices that mimic the kinematics of the intervertebral disc. The goal of this work is to trace the origins of cervical arthroplasty technology and highlight the attributes of devices currently available in the market. (DOI: 10.3171/2009.6.FOCUS09128)
\end{abstract}

\section{KeY WoRds • arthroplasty • cervical spine • history of neurosurgery}

$\mathrm{T}$ HE underlying hallmark of joint arthroplasty is the ability to preserve motion while maintaining stability. ${ }^{1}$ Motion-preserving joint prostheses have been widely used in orthopedic surgery, particularly in the treatment of degenerative hip and knee diseases. ${ }^{15,21}$ The notion that this technology could be applied in spinal disc disease, however, has been met with mixed feelings. The principal reasons behind this tempered enthusiasm, particularly in disorders of the cervical spine, are the highly predictable and largely favorable results of arthrodesis. $^{2-4}$

A better understanding of ASD, however, has been slowly changing attitudes toward fusion. Hilibrand et al. ${ }^{17}$ demonstrated an ASD rate of $2.9 \%$ /year, leading to a significant number of reoperations. Similar studies by Katsuura et al. ${ }^{18}$ and Goffin et al. ${ }^{13}$ reported ASD rates as high as 50 and $36 \%$, respectively. With biomechani$\mathrm{cal}^{10}$ and clinical ${ }^{13,17,18,30}$ data demonstrating progression of ASD in the cervical spine after arthrodesis, interest in motion-preserving technology is likely to continue. The goal of this review was to highlight the history of this technology and to discuss the principal devices currently available in the market.

\footnotetext{
Abbreviations used in this paper: $\mathrm{ACDF}=$ anterior cervical discectomy and fusion; ASD = adjacent-segment disease; CCM $=$ cobalt-chromium-molybdenum; IDE = investigational device exemption; $\mathrm{PCM}=$ porous coated motion; $\mathrm{ROM}=$ range of motion; UHMWPE = ultra-high molecular weight polyethylene.
}

\section{Cervical Arthroplasty Biomechanics}

Biomechanical testing and design configuration of cervical disc prostheses have been key in the development of this technology. Material designs include the following: metal-on-metal, metal-on-polymer, ceramicon-polymer, polymer composite, or ceramic-on-ceramic designs. ${ }^{35}$ Prostheses are further divided into constrained, unconstrained, and semiconstrained types, based on degrees of motion allowed (Table 1). The "best" configuration or design of a cervical artificial prosthesis is one that most closely mimics normal intervertebral disc kinematics. Consensus on which design accomplishes this goal, however, has not been clearly established. Kinematics, wear properties, stiffness, durability, and imaging compatibility are only some of the features that are taken into consideration in the design of these prostheses.

Biomechanical arthroplasty testing, as compared with arthrodesis testing, represents unique challenges. The goal is to measure parameters that accurately depict whether the instrumented spinal segment is behaving similarly to the intact spine. Measuring a simple ROM, which is the most commonly measured parameter in rigid fixation protocols, is insufficient in arthroplasty testing. Adjacent-segment ROM, coupling patterns, facet loading, intradiscal pressures, and postural changes are a few examples of useful biomechanical parameters for full characterization of cervical arthroplasty.

Not addressing these parameters, in our opinion, was a weakness in many of the earlier studies (Table 2). More 
A. A. Baaj et al.

TABLE 1: Cervical arthroplasty devices available in the US as of $2006 *$

\begin{tabular}{llll}
\hline Name of Device & \multicolumn{1}{c}{ Manufacturer } & Classification & Biomaterials \\
\hline PCM & NuVasive, Inc., San Diego, CA & semiconstrained & CCM end plate w/ UHMWPE inlay \\
ProDisc-C & Synthes Spine, West Chester, PA & semiconstrained & CCM end plate w/ UHMWPE inlay \\
Bryan & Medtronic, Ltd., Memphis, TN & unconstrained & titanium alloy shells w/ polyurethane nucleus \\
Prestige ST, & Medtronic, Ltd., Memphis, TN & unconstrained & metal-on-metal (ST device: stainless steel; \\
Prestige LP & & & LP device: titanium ceramic composite) \\
Kineflex-C & Spinal Motion, Inc., Mountain View, & semiconstrained & CCM metal-on-metal \\
& CA & & \\
CerviCore & Stryker Spine, Allendale, NJ & semiconstrained & CCM metal-on-metal \\
\hline * According to information in the article by Traynelis. Please note: not all devices are FDA approved.
\end{tabular}

recent studies were able to incorporate advanced testing techniques, including measuring intradiscal pressure and facet loads. ${ }^{59}$ Panjabi ${ }^{26}$ proposed a "hybrid" protocol for construct testing of spinal arthroplasty. In this technique, a load control is used in normal specimens to determine the limiting angles in each mode, after which displacement control is used for testing the remaining conditions. A potential problem with this method is that fused specimens are forced to undergo unrealistically excessive rotation, and this biases experiments unrealistically in favor of arthroplasty.

In our biomechanics lab at Barrow Neurological Institute, we have designed a specific protocol for gathering more extensive biomechanical data on cervical arthroplasty devices. In addition to simple ROM, we measure coupling patterns, instantaneous axis of rotation, alterations to upright posture, and facet loads by using strain gauges (unpublished data). Both traditional pure-moment loading and more physiological flexion and extension with compressive follower load are applied to the specimens (Fig. 1).

Using this more extensive protocol, we have initiated studies on several of the commercially available cervical devices. In 3 separate studies, we evaluated the kinematics of the cervical spine after insertion of the CerviCore, Pro-Disc C, and Prestige devices (our unpublished data). Comparisons were made to the normal and fused states. Results showed that these total disc replacement systems allowed for ROM, instantaneous axis of rotation, and coupling patterns that closely mimicked the normal state when compared with fusion. Testing to compare the kinematics of Bryan to Prestige devices is currently underway.

Developing and refining biomechanics testing methodologies for better assessment of the kinematics of cervical arthroplasty devices will be key as this technology is further embraced by clinicians and patients alike.

\section{Early Experience}

\section{First Artificial Cervical Device}

Ulf Fernstrom is credited with implanting the first artificial cervical device, in $1966 .{ }^{11}$ The implant was a stainless steel ball bearing prosthesis that was implanted in both lumbar and cervical regions of the spine. In total,
Fernstrom inserted 191 lumbar spheres and 13 cervical spheres. During the same time, another group from South Africa was experimenting with the Fernstrom type device in the cervical spine. ${ }^{29}$ The primary indications were headaches and cervicobrachialgia. Clinical follow-up, however, demonstrated unacceptable rates of device subsidence, migration, and adjacent-segment hypermobility. ${ }^{20}$ Given these failures, interest in cervical arthroplasty diminished in favor of arthrodesis techniques developed by Smith and Robinson. ${ }^{31}$

\section{The Cummins-Bristol Disc}

Given the popularity and widespread use of lumbar arthroplasty devices in the 1980s and 1990s, principally in Europe, the feasibility of motion preservation in the cervical spine gained renewed interest. One of the first prototypes was designed by B.H. Cummins at the Frenchay Hospital in Bristol, UK, in 1989. In a 2004 review, Le et al. ${ }^{20}$ described this as a 2-piece, metal-on-metal device composed of stainless steel. The articulating surface was a ball-and-socket design with 2 (initially 1 ) anterior anchoring screws that fixed each piece of the device to the adjacent vertebral bodies. Initial clinical results in the 18 patients available for follow-up were discouraging, however, with 3 cases of screw pullout, 1 of screw breakage, and 1 subluxed joint. ${ }^{6}$ Persistent dysphagia was reported in all 18 patients.

\section{The Prestige Disc}

Due to the high hardware failure rate and high-profile design of the Cummins-Bristol device, the prosthesis was redesigned and reintroduced as the Frenchay cervical disc. The articulating surface of the lower piece, the profile of the entire device, and the anterior locking mechanisms were all redesigned. The initial pilot study in 2002 demonstrated favorable results, with lower complication rates. ${ }^{34}$ With these initial results, further studies were undertaken to examine the efficacy of this device (later acquired by Medtronic, Inc., and renamed the Prestige Disc [Fig. 2]), with particular interest in progression of ASD. ${ }^{33}$ In 2007, the first randomized clinical trial in the US was performed to compare outcomes of Prestige disc implantation versus fusion. The results demonstrated that segmental motion was maintained with the device at 24 months as well as improved clinical outcomes, and found 


\section{Cervical disc arthroplasty}

TABLE 2: Peer-reviewed cervical arthroplasty biomechanics studies*

\begin{tabular}{|c|c|c|c|c|c|c|c|c|}
\hline $\begin{array}{l}\text { Authors } \\
\& \text { Year }\end{array}$ & Device & $\begin{array}{l}\text { Control } \\
\text { Type }\end{array}$ & $\begin{array}{l}\text { No. of } \\
\text { Speci- } \\
\text { mens }\end{array}$ & $\begin{array}{l}\text { Conditions } \\
\text { Tested \& Level }\end{array}$ & $\begin{array}{l}\text { Outcome } \\
\text { Measures }\end{array}$ & Results & Pros & Cons \\
\hline $\begin{array}{l}\text { McAfee } \\
\text { et al., } \\
2003\end{array}$ & PCM & load & 7 & $\begin{array}{l}\text { normal; C5/6 discec- } \\
\text { tomy sparing PLL; } \\
\text { device implanted; } \\
\text { device removed } \\
\text { \& PLL resected; } \\
\text { device replaced; } \\
\text { device removed \& } \\
\text { graft placed; plate } \\
\text { placed }\end{array}$ & $\mathrm{ROM}$ & $\begin{array}{l}\text { no significant differences btwn } \\
\text { normal \& PCM-implanted condi- } \\
\text { tions; PLL resection does not alter } \\
\text { biomechanics when PCM device } \\
\text { implanted }\end{array}$ & $\begin{array}{l}\text { highlights } \\
\text { signifi- } \\
\text { cance of } \\
\text { PLL in } \\
\text { uninstru- } \\
\text { mented } \\
\text { proce- } \\
\text { dures }\end{array}$ & $\begin{array}{l}\text { no adjacent- } \\
\text { level data; data } \\
\text { reported do not } \\
\text { separate flexion } \\
\text { \& extension } \\
\text { (combined data } \\
\text { are presented) }\end{array}$ \\
\hline $\begin{array}{l}\text { DiAnge- } \\
\text { lo et al., } \\
2003\end{array}$ & Prestige & $\begin{array}{l}\text { displace- } \\
\text { ment }\end{array}$ & 4 & $\begin{array}{l}\text { normal; } C 5 / 6 \text { prosthe- } \\
\text { sis; simulated fusion }\end{array}$ & $\begin{array}{l}\text { global } \\
\text { stiffness \& } \\
\text { ROM }\end{array}$ & $\begin{array}{l}\text { fusion decreases motion at replaced } \\
\text { level; prosthesis does not }\end{array}$ & $\begin{array}{l}\text { provides } \\
\text { adjacent- } \\
\text { level ROM }\end{array}$ & $\begin{array}{l}\text { axial rotation not } \\
\text { studied; fusion } \\
\text { specimens } \\
\text { forced similar } \\
\text { displacement } \\
\text { to nonfused } \\
\text { specimens }\end{array}$ \\
\hline $\begin{array}{l}\text { Puttlitz } \\
\text { et al., } \\
2004\end{array}$ & $\begin{array}{l}\text { Pro- } \\
\text { Disc-C }\end{array}$ & load & 6 & $\begin{array}{l}\text { normal; } C 4 / 5 \text { pros- } \\
\text { thesis }\end{array}$ & $\begin{array}{l}\text { ROM, } \\
\text { coupling } \\
\text { patterns }\end{array}$ & prosthesis mimicked normal ROM & $\begin{array}{l}\text { tested w/ } \\
\text { \& w/0 } \\
\text { preload }\end{array}$ & $\begin{array}{l}\text { adjacent levels } \\
\text { not studied; } \\
\text { combined flex- } \\
\text { ion \& extension } \\
\text { data }\end{array}$ \\
\hline $\begin{array}{l}\text { DiAnge- } \\
\text { lo et al., } \\
2004\end{array}$ & $\begin{array}{l}\text { Pro- } \\
\text { Disc-C }\end{array}$ & $\begin{array}{l}\text { displace- } \\
\text { ment }\end{array}$ & 6 & $\begin{array}{l}\text { normal; C5/6 prosthe- } \\
\text { sis; simulated fusion }\end{array}$ & $\begin{array}{l}\text { stiffness \& } \\
\text { ROM }\end{array}$ & $\begin{array}{l}\text { fusion decreases motion at replaced } \\
\text { level; prosthesis does not; 35\% } \\
\text { more flexion occurred w/ disc vs } \\
\text { normal (statistically insignificant), } \\
43 \% \text { less extension w/ disc vs } \\
\text { normal (significant) }\end{array}$ & $\begin{array}{l}\text { robotic } \\
\text { actuator } \\
\text { mimics in } \\
\text { vivo loads }\end{array}$ & $\begin{array}{l}\text { fusion specimens } \\
\text { forced similar } \\
\text { displacement } \\
\text { to nonfused } \\
\text { specimens }\end{array}$ \\
\hline $\begin{array}{l}\text { Kotani } \\
\text { et al., } \\
2005\end{array}$ & $\begin{array}{l}\text { disc } \\
\text { proto- } \\
\text { type }\end{array}$ & load & 7 & $\begin{array}{l}\text { normal; } \text { C5/6 pros- } \\
\text { thesis; graft; graft + } \\
\text { plating }\end{array}$ & $\mathrm{ROM} \& \mathrm{NZ}$ & $\begin{array}{l}\text { prosthesis maintained ROM \& NZ } \\
\text { vs normal in axial rotation \& lateral } \\
\text { bending; disc allowed greater ROM } \\
\text { (but not NZ) vs normal in flexion \& } \\
\text { extension }\end{array}$ & $\begin{array}{l}\text { adjacent- } \\
\text { segment } \\
\text { ROM } \\
\text { quantified }\end{array}$ & $\begin{array}{l}\text { combined flexion } \\
\text { \& extension } \\
\text { data }\end{array}$ \\
\hline $\begin{array}{l}\text { Dmi- } \\
\text { triev } \\
\text { et al., } \\
2005\end{array}$ & PCM & $\begin{array}{l}\text { dis- } \\
\text { place- } \\
\text { ment } \\
\text { (hy- } \\
\text { brid) }\end{array}$ & 10 & $\begin{array}{l}\text { normal; } C 5 / 6 \text { pros- } \\
\text { thesis; graft; graft } \\
\text { + plate }\end{array}$ & $\begin{array}{l}\mathrm{ROM}+ \\
\mathrm{NZ} \mathrm{C5/6} \\
\mathrm{ROM}+ \\
\text { intradis- } \\
\text { cal pres- } \\
\text { sures at } \\
\text { C4/5 \& } \\
\mathrm{C} 6 / 7\end{array}$ & $\begin{array}{l}\text { intradiscal pressure at adjacent } \\
\text { levels similar to normal after } \\
\text { prosthesis, significantly increased } \\
\text { after graft or graft + plate; ROM \& } \\
\text { NZ at index level mimicked normal } \\
\text { after disc replacement, but signifi- } \\
\text { cantly decreased after inserting } \\
\text { graft or graft + plate }\end{array}$ & $\begin{array}{l}\text { adjacent- } \\
\text { level } \\
\text { ROM \& } \\
\text { intradiscal } \\
\text { pressures } \\
\text { analyzed }\end{array}$ & $\begin{array}{l}\text { combined flexion } \\
\& \text { extension } \\
\text { data; fusion } \\
\text { specimens } \\
\text { forced similar } \\
\text { displacement } \\
\text { to nonfused } \\
\text { specimens }\end{array}$ \\
\hline $\begin{array}{l}\text { Mc- } \\
\text { Afee } \\
\text { et al., } \\
2006\end{array}$ & PCM & load & 6 & $\begin{array}{l}\text { normal; discectomy; } \\
\text { radical discec- } \\
\text { tomy; PCM; unilat } \\
\text { uncovertebral } \\
\text { resection + PCM; } \\
\text { bilat uncovertebral } \\
\text { resection + PCM }\end{array}$ & ROM; NZ & $\begin{array}{l}\text { ROM \& NZ mimicked normal condi- } \\
\text { tion, except in axial rotation w/ } \\
\text { bilat uncovertebral resection }\end{array}$ & $\begin{array}{l}\text { graded } \\
\text { anterior } \\
\text { resections } \\
\text { studied }\end{array}$ & $\begin{array}{l}\text { adjacent seg- } \\
\text { ments not } \\
\text { studied }\end{array}$ \\
\hline $\begin{array}{l}\text { Chang } \\
\text { et al., } \\
2007\end{array}$ & $\begin{array}{l}\text { Pres- } \\
\text { tige, } \\
\text { Pro- } \\
\text { Disc-C }\end{array}$ & $\begin{array}{l}\text { displace- } \\
\text { ment }\end{array}$ & 18 & $\begin{array}{l}\text { normal; prosthesis; } \\
\text { graft + plating, C6-7 }\end{array}$ & $\begin{array}{l}\text { ROM, IDP, } \\
\text { facet } \\
\text { loads }\end{array}$ & $\begin{array}{l}\text { increased IDP level above in fused } \\
\text { specimens; facet loads increased } \\
\text { w/ arthroplasty in extension }\end{array}$ & $\begin{array}{l}\text { facet loads, } \\
\text { IDP } \\
\text { measure- } \\
\text { ments }\end{array}$ & $\begin{array}{l}\text { only } 1 \text { strain } \\
\text { gauge used } \\
\text { in facet load } \\
\text { measurements }\end{array}$ \\
\hline
\end{tabular}

* IDP = intradiscal pressure; $\mathrm{NZ}$ = neutral zone; $\mathrm{PLL}=$ posterior longitudinal ligament 

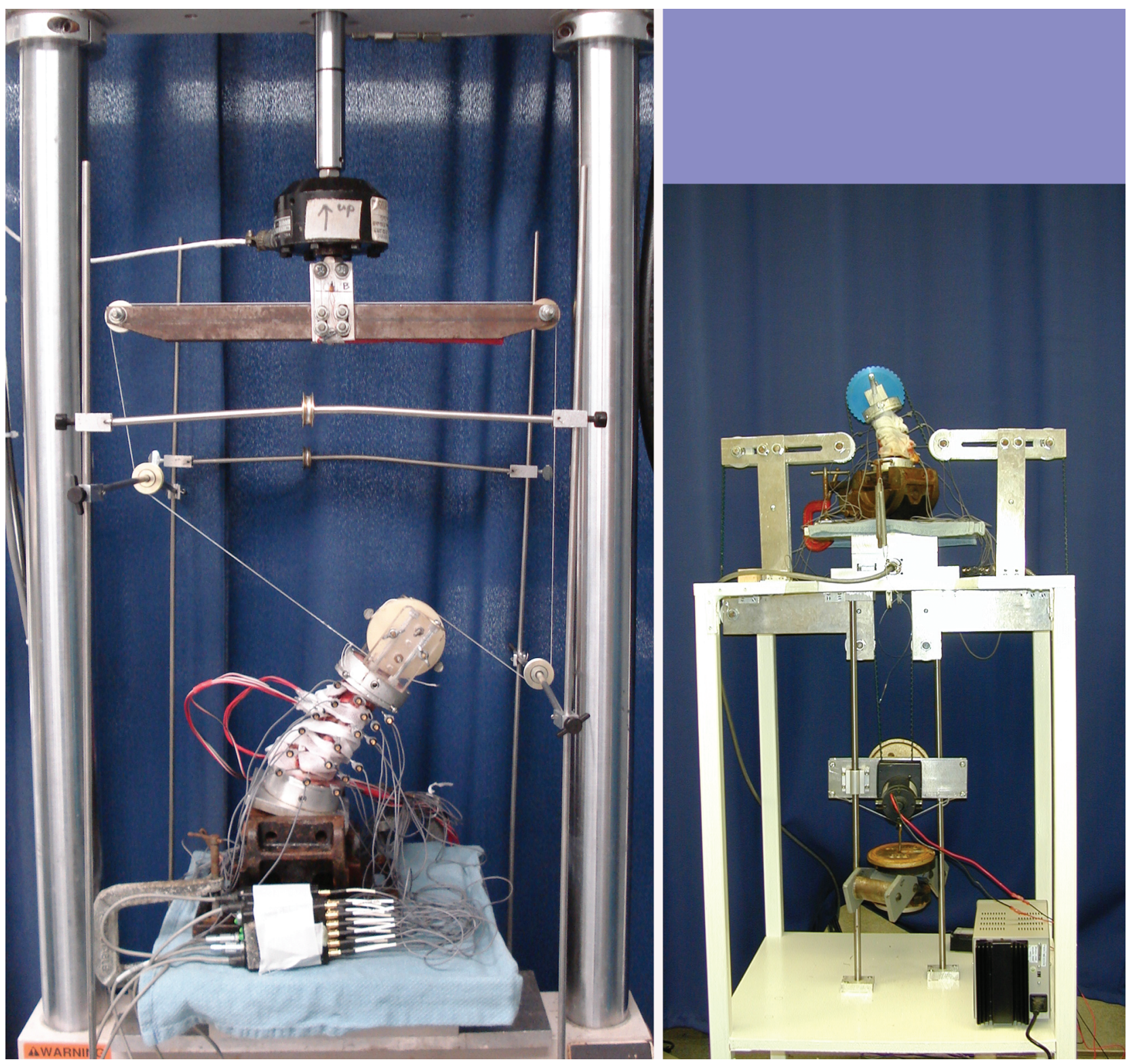

FIG. 1. Left: Photograph of the pure-moment, flexibility apparatus. When the piston of the servohydraulic test frame is raised, tension is exerted on the loop of string, applying equal and opposite forces separated by a small distance to the fixture on the specimen. Right: Photograph of the flexion-compression apparatus. Weights hung from a belt looped around the specimen apply a constant follower load of $70 \mathrm{~N}$; when the motor is activated, the belt drives the specimen into flexion or extension while keeping the follower load directed axially.

a reduced rate of secondary surgeries compared with ACDF. ${ }^{24}$ In July 2007, the Prestige disc was approved by the FDA for the treatment of intractable radiculopathy and/or myelopathy caused by a herniated disc between the C-3 and C-7 levels. The initial device (Prestige ST) was a metal-on-metal construct composed of stainless steel. The newer Prestige LP model (fifth-generation Prestige model) is composed of a titanium-ceramic composite that is MR imaging-compatible. A porous titanium plasma spray coating is designed to facilitate bone in-growth. This model is currently being evaluated in an FDA IDE trial.

\section{The Bryan Disc}

The Bryan cervical disc (Medtronic, Inc.) was designed in the 1990s by the American neurosurgeon Vincent Bryan from Seattle. The device consists of 2 titanium alloy shells articulating with a polyurethane core (Fig. 3). Like the Prestige disc, it is a considered an unconstrained device. This device is not held in the disc space with any hardware, and it requires a tight fit of the prosthesis into a milled concavity. Bone ingrowth eventually bonds the metallic device faces to the vertebrae. The first multicenter trial evaluating the safety and efficacy of 
Cervical disc arthroplasty

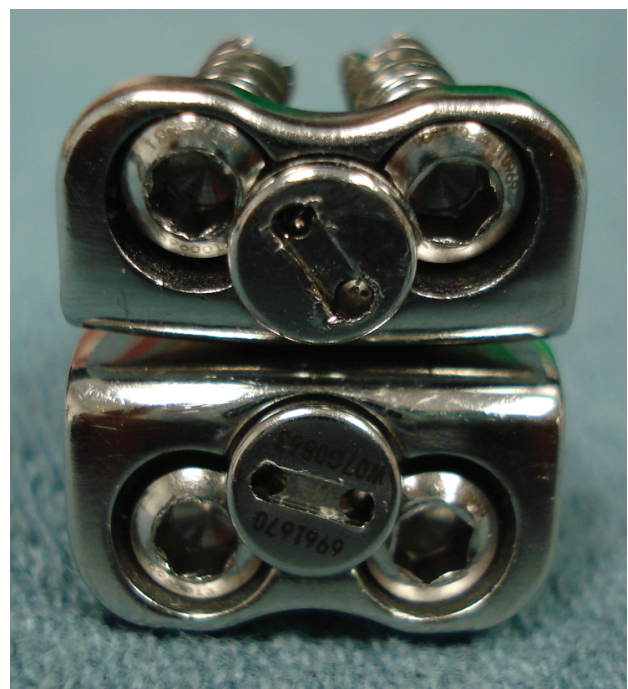

FIG. 2. Photograph of the Prestige ST cervical device.

this device was conducted in Europe..$^{12}$ The investigators found that clinical success at 6 months and 1 year after implantation was 86 and $90 \%$, respectively. At 1 year, there was no evidence of hardware failure, but there was 1 case of device migration that did not warrant revision surgery. Other European studies further demonstrated the efficacy of the Bryan device, even with bilevel implantation. ${ }^{14}$ Available data from the current US IDE trial are promising. In a recent publication, ${ }^{16}$ the investigators found that at 24 months after surgery, the patients in the investigational group treated with the artificial disc had a statistically greater improvement in the primary outcome variables compared with the control group (single-level $\mathrm{ACDF}$ ). There was a $1.7 \%$ rate of implant-associated or implant/surgical procedure-associated serious adverse events in the investigational group, compared with $3.2 \%$ in the control group. Patients who received the artificial cervical disc returned to work nearly 2 weeks earlier than the patients who underwent fusion.

\section{The ProDisc-C Device}

The ProDisc-C device (Synthes, Inc.) was invented by Dr. Thierry Marnay of France. It was designed to parallel the ProDisc-L device used in lumbar arthroplasty.

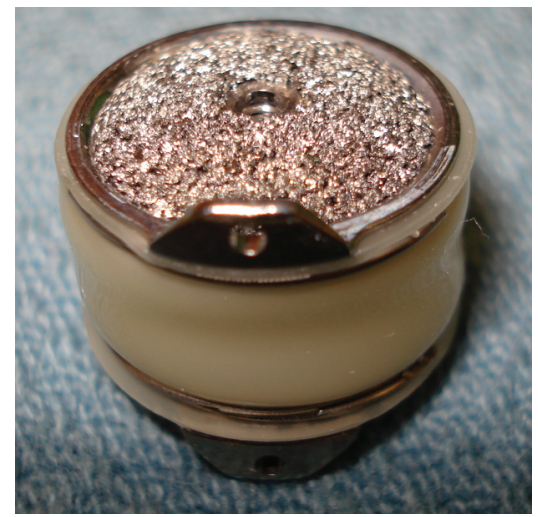

FIG. 3. Photograph of the Bryan cervical device.

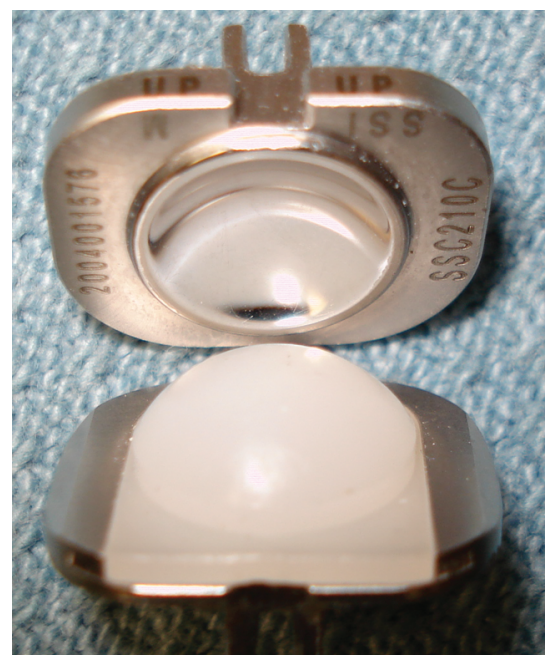

FIG. 4. Photograph of the ProDisc-C cervical device.

It is a semiconstrained device composed of CCM end plates, with a UHMWPE articulating surface (Fig. 4). Two keels on each external surface facilitate anchoring into the vertebral end plates. Results of the FDA IDE trial were recently published..$^{25}$ Investigators found that neck pain intensity and frequency as well as arm pain intensity and frequency assessed using the visual analog scale were statistically lower at all follow-up time points compared with preoperative levels ( $p<0.0001$ ), but were not different between treatments (disc group vs ACDF group). Neurological success (improvement or maintenance) was achieved at 24 months in $90.9 \%$ of ProDisc-C and $88 \%$ of fusion patients $(\mathrm{p}=0.638)$. There was a statistically significant difference in the number of secondary surgeries, with $8.5 \%$ of fusion patients needing a repeat operation, revision, or supplemental fixation within the 24-month postoperative period, compared with $1.8 \%$ of ProDisc-C patients $(p=0.033)$. In this study, the authors concluded that ProDisc- $\mathrm{C}$ is a safe and effective surgical treatment for patients with disabling cervical radiculopathy due to single-level disease, and that clinical outcomes after Pro-

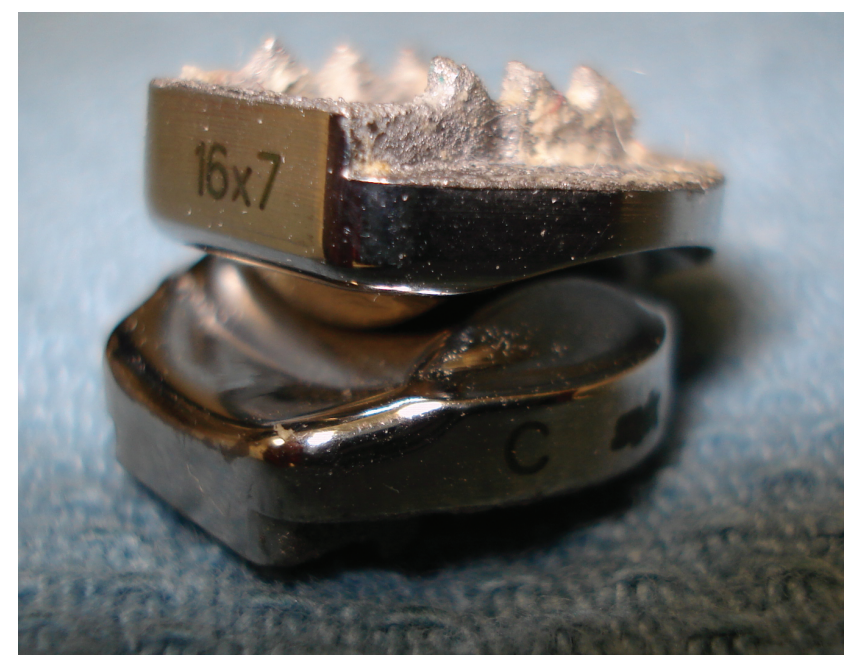

FIG. 5. Photograph of the CerviCore cervical device. 
Disc-C implantation were either equivalent or superior to those same clinical outcomes after fusion. The ProDisc-C was approved by the FDA in December 2007.

\section{The PCM Device}

The PCM device was invented by Paul McAfee, an orthopedic spine surgeon from Baltimore. The PCM is a 2-piece device consisting of a CCM end plate with a UHMWPE inner core. Its hallmark is a broad radius of curvature that allows for more end-plate support laterally. The device is coated with a titanium calcium phosphate coating to optimize end-plate anchorage. Initial results from McAfee's group ${ }^{27}$ are promising. This group's results from a pilot study in which 82 cervical disc arthroplasties were implanted in 53 patients demonstrated significant improvements in the indices examined. There was $1 \mathrm{de}-$ vice migration that did not require revision surgery. An FDA IDE study is ongoing. In 2009, NuVasive (NuVasive, Inc.) acquired this device.

\section{The CerviCore Device}

The CerviCore device (Stryker Spine) is a semiconstrained, metal-on-metal prosthesis. The articulating surface is saddle-shaped (Fig. 5), with 2 keels containing spikes present on each end plate. The saddle-shaped articulation is intended to provide different kinematics during lateral bending than during flexion and extension, as is seen naturally. Testing in our laboratory (unpublished data) showed that this particular total disc replacement system effectively preserves ROM and kinematics in the cervical spine. An FDA IDE trial is ongoing.

\section{Conclusions}

The last several decades have witnessed notable milestones in the development of cervical disc arthroplasty. The ultimate goal is to construct a device that stabilizes the involved segment, preserves motion, and mimics the kinematics of a healthy intervertebral disc. Given the evidence of adjacent-segment failure associated with arthrodesis, as well as encouraging results thus far from various clinical and biomechanical studies, the drive for further development of the cervical arthroplasty field is likely to continue.

\section{Disclosures}

The Spinal Biomechanics lab at Barrow Neurological Institute of St. Joseph's Hospital and Medical Center in Phoenix has received research funding from Medtronic Sofamor Danek, Synthes Spine Company, and Stryker Spine for biomechanics testing of cervical arthroplasty devices.

\section{References}

1. Albert TJ, Eichenbaum MD: Goals of cervical disc replacement. Spine J 4:292S-293S, 2004

2. Bohlman HH, Emery SE, Goodfellow DB, Jones PK: Robinson anterior cervical discectomy and arthrodesis for cervical radiculopathy. Long-term follow-up of one hundred and twenty-two patients. J Bone Joint Surg Am 75:1298-1307, 1993

3. Bose B: Anterior cervical fusion using Caspar plating: analy- sis of results and review of the literature. Surg Neurol 49:2531, 1998

4. Cauthen JC, Kinard RE, Vogler JB, Jackson DE, DePaz OB, Hunter OL, et al: Outcome analysis of noninstrumented anterior cervical discectomy and interbody fusion in 348 patients. Spine 23:188-192, 1998

5. Chang UK, Kim DH, Lee MC, Willenberg R, Kim SH, Lim $\mathrm{J}$ : Changes in adjacent-level disc pressure and facet joint force after cervical arthroplasty compared with cervical discectomy and fusion. J Neurosurg Spine 7:33-39, 2007

6. Cummins BH, Robertson JT, Gill SS: Surgical experience with an implanted artificial cervical joint. J Neurosurg 88:943-948, 1998

7. DiAngelo DJ, Foley KT, Morrow BR, Schwab JS, Song J, German JW, et al: In vitro biomechanics of cervical disc arthroplasty with the ProDisc-C total disc implant. Neurosurg Focus 17(3):E7, 2004

8. DiAngelo DJ, Robertson JT, Metcalf NH, McVay BJ, Davis RC: Biomechanical testing of an artificial cervical joint and an anterior cervical plate. J Spinal Disord Tech 16:314-323, 2003

9. Dmitriev AE, Cunningham BW, Hu N, Ito M, Shikinami Y, McAfee PC, et al: Adjacent level intradiscal pressure and segmental kinematics following a cervical total disc arthroplasty: an in vitro human cadaveric model. Spine 30:1165-1172, 2005

10. Eck JC, Humphreys SC, Lim TH, Jeong ST, Kim JG, Hodges $\mathrm{SD}$, et al: Biomechanical study on the effect of cervical spine fusion on adjacent-level intradiscal pressure and segmental motion. Spine 27:2431-2434, 2002

11. Fernstrom U: Arthroplasty with intercorporal endoprothesis in herniated disc and in painful disc. Acta Chir Scand Suppl 357:154-159, 1966

12. Goffin J, Casey A, Kehr P, Liebig K, Lind B, Logroscino C, et al: Preliminary clinical experience with the Bryan cervical disc prosthesis. Neurosurgery 51:840-847, 2002

13. Goffin J, Geusens E, Vantomme N: Long-term follow-up after interbody fusion of the cervical spine. J Spinal Disord Tech 17:79-85, 2004

14. Goffin J, Van Calenbergh F, van Loon J, Casey A, Kehr P, Liebig K, et al: Intermediate follow-up after treatment of degenerative disc disease with the Bryan cervical disc prosthesis: single-level and bi-level. Spine 28:2673-2678, 2003

15. Hamelynck KJ: The history of mobile-bearing total knee replacement systems. Orthopedics 29:S7-S12, 2006

16. Heller JG, Sasso RC, Papadopoulos SM, Anderson PA, Fessler RG, Hacker RJ, et al: Comparison of BRYAN cervical disc arthroplasty with anterior cervical decompression and fusion: clinical and radiographic results of a randomized, controlled, clinical trial. Spine 34:101-107, 2009

17. Hilibrand AS, Carlson GD, Palumbo MA, Jones PK, Bohlman $\mathrm{HH}$ : Radiculopathy and myelopathy at segments adjacent to the site of a previous anterior cervical arthrodesis. J Bone Joint Surg Am 81:519-528, 1999

18. Katsuura A, Hukuda S, Saruhashi Y: Kyphotic malalignment after anterior cervical fusion is one of the factors promoting the degenerative process in adjacent intervertebral levels. Eur Spine J 10:320-324, 2001

19. Kotani Y, Cunningham BW, Abumi K, Dmitriev AE, Ito M, $\mathrm{Hu} \mathrm{N}$, et al. Multidirectional flexibility analysis of cervical artificial disc reconstruction: in vitro human cadaveric spine model. J Neurosurg Spine 2:188-194, 2005

20. Le H, Thongtrangan I, Kim DH: Historical review of cervical arthroplasty. Neurosurg Focus 17(3):E1, 2004

21. Learmonth ID, Young C, Rorabeck C: The operation of the century: total hip replacement. Lancet 370:1508-1519, 2007

22. McAfee PC, Cunningham B, Dmitriev A, Hu N, Woo Kim S, Cappuccino A, et al: Cervical disc replacement-porous coated motion prosthesis: a comparative biomechanical analysis 


\section{Cervical disc arthroplasty}

showing the key role of the posterior longitudinal ligament. Spine 28:S176-S185, 2003

23. McAfee PC, Cunningham BW, Hayes V, Sidiqi F, Dabbah M, Sefter JC, et al: Biomechanical analysis of rotational motions after disc arthroplasty: implications for patients with adult deformities. Spine 31:S152-S160, 2006

24. Mummaneni PV, Burkus JK, Haid RW, Traynelis VC, Zdeblick TA: Clinical and radiographic analysis of cervical disc arthroplasty compared with allograft fusion: a randomized controlled clinical trial. J Neurosurg Spine 6:198-209, 2007

25. Murrey D, Janssen M, Delamarter R, Goldstein J, Zigler J, Tay $\mathrm{B}$, et al: Results of the prospective, randomized, controlled multicenter Food and Drug Administration investigational device exemption study of the ProDisc-C total disc replacement versus anterior discectomy and fusion for the treatment of 1-level symptomatic cervical disc disease. Spine J 9:275286, 2009

26. Panjabi MM: Hybrid multidirectional test method to evaluate spinal adjacent-level effects. Clin Biomech 22:257-265, 2007

27. Pimenta L, McAfee PC, Cappuccino A, Bellera FP, Link HD: Clinical experience with the new artificial cervical PCM (Cervitech) disc. Spine J 4:315S-321S, 2004

28. Puttlitz CM, Rousseau MA, Xu Z, Hu S, Tay BK, Lotz JC: Intervertebral disc replacement maintains cervical spine kinetics. Spine 29:2809-2814, 2004

29. Reitz H, Joubert MJ: Intractable headache and cervico-brachialgia treated by complete replacement of cervical intervertebral discs with a metal prosthesis. S Afr Med J 38:881-884, 1964
30. Robertson JT, Papadopoulos SM, Traynelis VC: Assessment of adjacent-segment disease in patients treated with cervical fusion or arthroplasty: a prospective 2-year study. J Neurosurg Spine 3:417-423, 2005

31. Smith GW, Robinson RA: The treatment of certain cervicalspine disorders by anterior removal of the intervertebral disc and interbody fusion. J Bone Joint Surg Am 40:607-624, 1958

32. Traynelis VC: Cervical arthroplasty. Clin Neurosurg 53:203207, 2006

33. Wigfield C, Gill S, Nelson R, Langdon I, Metcalf N, Robertson $\mathrm{J}$ : Influence of an artificial cervical joint compared with fusion on adjacent-level motion in the treatment of degenerative cervical disc disease. J Neurosurg 96:17-21, 2002

34. Wigfield CC, Gill SS, Nelson RJ, Metcalf NH, Robertson JT: The new Frenchay artificial cervical joint: results from a twoyear pilot study. Spine 27:2446-2452, 2002

35. Yi S, Lee DY, Kim DH, Ahn PG, Kim KN, Shin HC, et al: Cervical artificial disc replacement. Part 1: History, design, and overview of the cervical artifical disc. Neurosurg $\mathbf{Q}$ 18:89-95, 2008

Manuscript submitted May 19, 2009.

Accepted June 30, 2009.

Address correspondence to: Neil R. Crawford, Ph.D., Spinal Biomechanics, Barrow Neurological Institute, 350 West Thomas Road, Phoenix, Arizona 85013.email: neil.crawford@chw.edu. 